\title{
The Influence of Private Equity Fund for Small and Medium-sized Enterprise Development Research
}

\author{
Fang Cai ${ }^{1, a^{*}}$ and Zhan Wang ${ }^{2, b}$ \\ ${ }^{1}$ Hongshan district 122 Luoshi road of Wuhan University of Technology School of Management, \\ Wuhan, Hubei province, China \\ ${ }^{2}$ Hongshan district 122 Luoshi road of Wuhan University of Technology School of Management, \\ Wuhan, Hubei province, China \\ a1319317165@qq.com, bwangjue0121@163.com \\ * please mark the corresponding author with an asterisk
}

Keywords: Private equity funds (PE); Middle and small-sized enterprise (SMEs); Financing difficulty

\begin{abstract}
Private equity investment services as the third enterprises financing channel ranking next to bank credit and public financing. After 70 years of development in the Western developed market, it also has been booming development in Chinese market. Although there are few problems that impedes the development of private equity fund, such as imperfect legal system, fewer intermediary institutions, but in China, the use of PE solving a large number of enterprises especially the problem of insufficient funds of SMEs is of great practical significance. We first expounds the private-equity industry development present situation at home and abroad, then analyses the financing status of small and medium-sized enterprises, pointing out that the use of private equity fund is the necessity to solve the problem of its financing. Finally, put forward the suggestions to promote the development of private equity fund in China.
\end{abstract}

\section{Introduction}

Private Equity Fund (PE for short), after decades of rapid development, becomes the third largest corporate financing channel only second to bank loans and issue shares. In the development process of the small and medium-sized enterprises, the financing difficulty has been the bottleneck of restricting its development. Compared with bank loans, financing scale and enterprise's qualification of $\mathrm{PE}$ are relatively low, the most concerned and investigated are the core competitiveness, growth and business model of the invested enterprise. Compared with public finance, the "threshold" of PE financing is lower, so PE is more and more used to solve the financing difficulties of small and medium-sized enterprises in China.

$\mathrm{Fu}$ Yufeng (2015) comes to the conclusion that following the introduction of PE small and medium-sized enterprises improved greatly in cash flow, industrial structure, financial performance and management team, after analyzing PE and the development of SMEs using case studies [1]. Wu Jianjun, Xia Erhong and Li Fang (2008) conduct comparative analysis on four financing way of SMEs, find that PE is the most suitable way for SMEs [2]. Zhang Xiaorong and Huang Bei (2006) analyses overseas private equity successful cases, expects Chinese PE play an important role in the development of SMEs. They insist that PE can not only provide new financing channels, but also help enterprises to improve corporate governance and the quality of the management team [3]. Liu Tao (2016) argue that China's RMB fund has obvious advantages, the continuous expansion of its provides opportunity for the development of SMEs, at the same time, PE legislation should also be synchronous update [4].Wang Guangkai, Zhang Tao and Hong Min (2017) argue that PE promote enterprise growth via providing investment and financing support, promoting technological innovation and improving corporate governance structure, and realize the capital appreciation of the investment fund and the enterprise values of [5]. We intend to study the influence of introducing PE on small and medium-sized enterprises, and puts forward suggestions for the development of private equity fund in China. 


\section{PE Development and Research Status}

Private equity investment fund in China originally develop in the form of venture investment fund or risk investment. In 1985, entrepreneurial venture capital fund comes to the early shape with the support of the government. In 2005, the emergence of the non-entrepreneurial private equity funds marks private equity investment fund in China steps to the rational development stage under the government guidance. In 2005, CSRC puts forward the reform of non-tradable shares of listed companies, perfecting system; capital market financing function is restored. "The trust law of the People's Republic of China" in 2001, "trust company assemble funds plan management method" in 2007, and in 2008 the Chinese banking regulatory commission print and distribute "trust private equity investment trust business operating guidelines", and 2005 "the company law" and "the securities law", modifying "the partnership enterprise law" and other laws, have provided a legal basis for indenture system, corporations, and the establishment of a limited partnership private equity fund. The successful launch of the growth enterprise market (gem) offers an ideal way for private equity investment. Private equity investment fund get great development in this period.

Data of QingKe research center shows that in 2007 a total of 64 invest only Asian markets (including mainland China) private equity funds successfully raised 355.84 dollars, up $150.7 \%$ from 2006. At the same time, private equity investment institutions invest 177 cases in mainland China, with a total investment of us $\$ 1.2$ billion. In 2012, a total of $369 \mathrm{PE}$ invest only in mainland China, which is the record level. 359 of them revealed raise amount to a total of $\$ 25.313$ billion.

PE participate in investment activities particularly active in 2004, transaction volumes and value increased by $51 \%$ and $101 \%$ respectively, which are both the new records. They actively participate in restructuring state-owned enterprises and foreign mergers and acquisitions (transaction amount first reaches grade scale) is the rapid development of the main driving factor, see Fig.1.

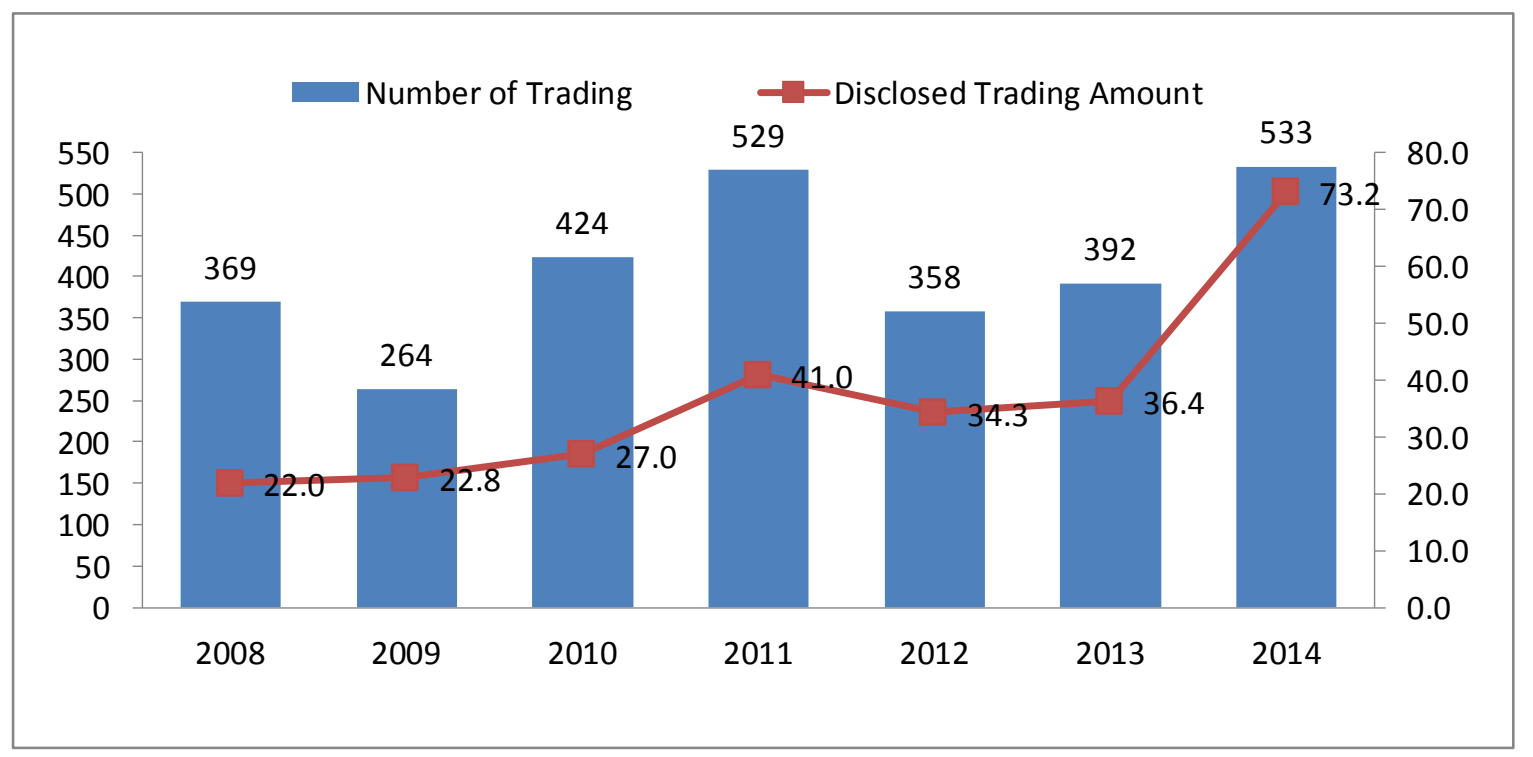

Figure 1. Finite

The main characteristics of Chinese private equity funds performance as follows: first, although the local private equity investment is growing rapidly, but overseas capital still occupy half of the scales. Second, investment more concentrated in the traditional industry. Third, corporations are still a major organizational form of private equity investment, but the proportion of partnership is growing.

\section{Analysis of PE in SMEs Financing}

About the definition of small and medium-sized enterprises, the national development and reform 
commission, ministry of finance formulate "the small and medium-sized enterprises (SMEs) row type standard regulations" made the following standards, as shown in Table 1.

Table 1 Current Chinese SMEs standard

\begin{tabular}{|c|c|c|c|c|c|}
\hline Industry & Employee & $\begin{array}{l}\text { operation revenue } \\
/ \text { million }\end{array}$ & Industry & Employee & $\begin{array}{l}\text { operation revenue } \\
\text { /million }\end{array}$ \\
\hline $\begin{array}{c}\text { Industrial } \\
\text { engineering }\end{array}$ & Under 1000 & Under 400 & $\begin{array}{c}\text { Industrial } \\
\text { engineering }\end{array}$ & Under 1000 & Under 300 \\
\hline $\begin{array}{l}\text { Construction } \\
\text { industry }\end{array}$ & & Under 800 & $\begin{array}{l}\text { Construction } \\
\text { industry }\end{array}$ & Under 200 & Under 300 \\
\hline $\begin{array}{l}\text { Wholesale } \\
\text { trade }\end{array}$ & Under 200 & Under 400 & $\begin{array}{l}\text { Wholesale } \\
\text { trade }\end{array}$ & Under 1000 & Under 300 \\
\hline Retail business & Under 300 & Under 200 & $\begin{array}{c}\text { Retail } \\
\text { business }\end{array}$ & Under 300 & Under 100 \\
\hline
\end{tabular}

Chinese SMEs are an important part of national economy; its development also has low technical content, small scale, no-standard financial system, rigid management methods, and a series of unique characteristics [6]. Before SMEs being listed, the introduction of PE can not only help alleviate the pressure of the financing, also accord with the investment of private equity investment fund desire [7].

From the development prospects of private equity funds, private equity financing play a more and more important role in way of SMEs financing [8]. First, SMEs' important status in the national economic and social development and the contradiction of their financing difficulties situation determines the private equity financing must be developed. SMEs are the important economy pillar of the national and help alleviate employment pressure, maintain social stability. Second, the adjustment of industrial structure requires the combination of PE and SMEs. the proportion of heavy industry accounted for the national economy has been overweight, and industrial structure adjustment has become a national development strategy in China. The development PE helps to promote national industry structure adjustment, because strategic direction for private equity funds and macro economy basic consistent. Third, Chinese private equity financing market is very bright in the future. In the word, PE has become the third financing means only second to bank loans, issue shares. In China, scale of equity investment fund industry including the VC (venture capital funds), PE (private equity funds) is greatly fall behind from developed countries. Chinese securities investment amount is more than 3 trillion yuan, and equity investment just tens of billions yuan, both in the United States these two financing scale is basically equal. In recent years, PE increasingly improves Chinese direct financing channel congestion, and awakes the attention from all fields. Chinese government expects industry funds to lead Chinese industry transformation under the background of financial crisis. PE is becoming more and more important financing channels.

\section{Suggestions to Promote the Development of PE in China}

In this section, we put forward suggestion from two levels, one is the macro level, and one is micro level suggestion.

Macro Suggestions including perfecting the supervision model of Chinese PE, improving the legal system of private equity fund [9]. For PE regulation, it is necessary to do from three aspects. It is based on the existing laws and regulations, such as investigating and punishing insider trading, which can be solved by laws and regulations. The second is to furtherly adjust the existing laws. Such as investors including PE propose "attach to the switch", in order to avoid the concerned parties taking flight, we can lock the rights, rights trading are strictly prohibited before the shareholders' meeting review proposal. The third is to perfect and strengthen PE relevant laws and regulations as soon as possible, make the development of PE steps into the orbit of legalization. As for Chinese PE, "the securities law", "the company law" and "the partnership enterprise law" have 
provided a legal basis for it, but the present legal norms are still insufficient. To attract customers, most PEs privately committed to customers, such as to assure the safety of capitals or ensure annual return. Actually, this neither the partnership nor the investment contract is illegal fund raising. In the case, even if there is a written contract, it is hard to get legal protection. As we can see, there is no officially laws and regulations to define PE which is the source of private equity financing for SMEs, it is still on the stage of exploration and experiment.

Micro-level suggestions include cultivating Chinese PE professionals, effectively implementing of the PE management, actively carrying out mergers and acquisitions exit. Due to its high expertise, Chinese financing market needs a batch of professional talents with clear recognition to the market and the development of the industry. We can introduce talents from international financial professionals, at the same time, develop our PE professional talents. In the whole process of management in PE, raising and investment process is very mature, exit mechanism has fusion within the investment trading on strategy, but its implementation is greatly depend on investment banks and other financial intermediaries. Relatively, after-investment management has rarely given enough attention. After-investment management should pay attention to veto settings of the investment agreement and articles, three practical operation, daily supervision, the establishment of the abnormal coping mechanism, etc. Exit of PE may happen when enterprise is merged by listed companies, private equity funds is a small shareholders of the project company and then the shares of its stock can quit after one year.

\section{Research Conclusion}

We analyzes the development status of PE, discusses the necessity and positive significance of using PE to solve Chinese SMEs' enterprise financing difficulty. We put forward the legal system to perfect PE regulation, build and perfect the supervision system of PE in China, establish intermediary market system and cultivating qualified fund management professional talent and so on, to promote PE develop better in China.

Although we propose the necessity of using PE to solve the financing difficulties of SMEs, and put forward suggestions for the development of PE from macro and micro level, but the study is not intensive enough. We will base on existing research, and continue focusing on the development of PE related progress, furtherly study relevant theoretical problems.

\section{References}

[1] Fu Yufeng. Private equity funds to promote the development of China's small and medium-sized enterprise application research [D]. North China electric power university, 2015. (In Chinese)

[2] Wu Jianjun, Xia Erhong, Li Fang. Small and medium-sized private enterprises of private equity financing advantage and risk control [J]. Journal of Accounting Communication(finance), 2008. (01): 34 - 35. (In Chinese)

[3] Zhang Xiaorong, Huang Bei. Private equity: small and medium-sized enterprise financing new channels [J]. Journal of Zhejiang Finance, 2006, (6): 27-29. (In Chinese)

[4] Liu Tao. Private equity investment: current situation, opportunities and development [J]. Journal of Modern Communication, 2016, (4): 54-55. (In Chinese)

[5] Wang Guangkai, Zhang Tao and HongMin. Private equity investment to the enterprise growth promoting effect of study[J]. Journal of Modern Management Science, 2017, (7), 18 - 20. (In Chinese)

[6] $\mathrm{Xu} \mathrm{Li}$. The empirical study of factors affecting to small and medium-sized enterprise financing [D]. Tianjin: Tianjin University of Finance and Economics, 2010. (In Chinese)

[7] Ben. Hamad. Financial decision and global financial behavior of small and medium enterprise[J]. Thesis of doctorate,2004;77-85.

[8] Jason kelly. Private empire: the truth of the big global PE to rule the world [M]. Beijing: mechanical industry press, 2013:201-211. (In Chinese) 
[9] Liang Sansan, Jiao Qisen. The influence of private equity funds for small and medium-sized enterprises [J]. Chinese and Foreign Entrepreneurs, 2014: (01), 89-90. (In Chinese) 